International Research Journal of Management, IT \& Social Sciences
Available online at https://sloap.org/journals/index.php/irjmis/
Vol. 6 No. 2, March 2019, pages: 31 43
ISSN: 2395-7492
https://doi.org/10.21744/irjmis.v6n2.604

\title{
The Effect of Auditor Experience, Type of Personality and Fraud Auditing Training on Auditors Ability in Fraud Detecting with Professional Skepticism as a Mediation Variable
}

\begin{abstract}
CrossMark
Gede Sanjaya Adi Putra ${ }^{a}$ Anak Agung Ngurah Bagus Dwirandra ${ }^{\text {b }}$

Article history:

Received: 27 September 2018

Accepted: 31 January 2019

Published: 16 March 2019

\section{Keywords:}

audit experience; auditor ability;

fraud audit training;

personality type;

professional skepticism;

Abstract

The occurrence of fraud or intentional actions that do not appear at the time of auditing will have a negative impact on financial reporting. Along with the development of the times, fraud is increasingly prevalent. And the greater the public demand that the auditor can detect fraud, is something that the auditor must respond to. Data collection was carried out using a questionnaire, with 71 respondents consisting of all auditors working in the Public Accounting Office (KAP) spread across Bali Province. Respondents were selected based on the purposive sampling method. The analysis technique used is Partial Least Square (PLS). The results showed that audit experience, personality type, cheating audit training, and professional skepticism had a significant positive effect on the auditor's ability to detect fraud. And skepticism of being able to become a mediator is partially mediated by audit experience variables, personality types, and fraud audit training on the auditor's ability to detect. Future studies are expected to be able to expand the scope of the research area and use other variables that have not been used in this study.
\end{abstract}

2395-7492@ Copyright 2019. The Author. This is an open-access article under the CC BY-SA license (https://creativecommons.org/licenses/by-sa/4.0/) All rights reserved.

\section{Author correspondence:}

Gede Sanjaya Adi Putra,

Faculty Economic and Business of Udayana University, Bali, Indonesia.

Email address: rasumaputri80@gmail.com

\section{Introduction}

The occurrence of fraud or intentional actions that do not appear at the time of auditing will have a negative impact on financial reporting. Along with the development of the times, fraud is increasingly prevalent. The fraud was carried out in various ways, many cases of accounting manipulation that had a serious impact involving well-known public accounting firms. This makes financial statement user confidence decrease (Dwiranda et al., 2017).

Almost every year fraud occurs in large companies that are not detected by the auditors in charge of auditing, international scale cases are Enron, World com cases and cases that occurred in 2005 where the auditor made a mistake

a Faculty Economic and Business of Udayana University, Bali, Indonesia

${ }^{\mathrm{b}}$ Faculty Economic and Business of Udayana University, Bali, Indonesia 
in auditing financial statements of Adelphia Communications Corp, and involved accounting fraud when Tyco overstated its revenues in 2007. Then when auditing MFS's Premium Income Fund in 2009, the auditor was deemed to have failed to detect unsuitable loans to foreign companies that did not have the ability to pay the total loans (Aulia, 2013).

In Indonesia, there are still frequent cases of fraud in financial reporting. Maulana (2014), stated that one of the most widely reported cases was the involvement of 10 KAPs in Indonesia in the practice of financial fraud. The KAPKAP was appointed to audit 37 banks before the financial crisis in 1997. The results of the audit revealed that the banks' financial statements were sound. When the crisis hit Indonesia, the banks collapsed because of their poor financial performance. This was revealed in an investigation conducted by the government that the KAP-KAP was involved in the practice of accounting fraud.

The auditor's ability to detect fraud is expertise possessed by an auditor in finding the lack of skill, and then the auditor uses his expertise to disclose and explain the deficiencies (Dwirandra \& Suryanawa, 2018). Auditors' abilities must be increased to reduce failure in detecting fraud to maintain the reliability of audited financial statements. However, auditors are required to be able to detect fraud in the event of fraud in carrying out their audit duties. However, the problem that arises is that each auditor has a different ability to detect fraud. Seen from different audit experiences, different personality types, different Frequency of Audit Training Fraud, and also different attitudes of skepticism.

Professional skepticism is considered important for an auditor in assessing audit evidence. This skepticism is a critical attitude in assessing audit evidence which is then considered with the adequacy and suitability of the available evidence so that the audit evidence can obtain high confidence. Beasley et al., (2001), based on AAERs (Accounting and Auditing Enforcement Releases) cited by Noviyanti (2008), state that one of the causes of auditor failure in detecting fraud is the low level of professional skepticism held by auditors. Nasution \& Fitriany (2012), explain further if auditors are more skeptical, they will be able to estimate the existence of fraud at the planning stage of the audit, which will ultimately direct the auditor to increase fraud detection during the next audit stages.

With an attitude of skepticism, the auditor will not immediately believe what his client explained. That does not mean the auditor does not trust his client at all. Because, when someone commits fraud, they will not tell directly what they have done. Low auditor skepticism causes auditors to be unable to detect fraud and tend to trust their clients directly. That way the auditor will only find mistakes, not fraud. If the auditor's skepticism is high, he will ask questions to get clear evidence of the problem, so the possibility of fraud is getting smaller.

Professional skepticism and the auditor's ability to detect fraud are also strongly influenced by the auditor's experience. Audit experience is one of the factors that influence the auditor's professional skepticism and the auditor's ability to detect fraud. The audit experience is indicated by the auditor's flight hours in conducting audit procedures related to giving opinions on the audit report. The more an auditor checks financial statements, the higher the level of professional skepticism the auditor has (Winantyadi \& Waluyo, 2014). Experienced auditors certainly have a lot of knowledge in their minds so they can be more critical of audit evidence.

Hasanah (2010), also stated that an auditor's experience and understanding of the types and characteristics of fraud will greatly assist in the preparation and implementation of inspection procedures. There is a tendency for the financial report presenter to hide a fraud that will occur, for this reason, an auditor who is truly experienced in accordance with the field of examination is his task.

Experienced auditors must have done many audit assignments, so they have found cases of fraud and have extensive knowledge and good thinking to resolve the case. Because the frequency of fraud is not frequent, it means that not all auditors have encountered cases of fraud. Experienced auditors tend to have good skepticism to improve their ability to detect fraud.

Personality type is a factor that is often overlooked to increase professional skepticism and the auditor's ability to detect fraud. Not everyone can be a good auditor, the auditor is required to be able to adjust to certain situations or circumstances when conducting an audit. Turban et al., (2005), stated that personality types influence one's decision making. Personality types affect general orientation towards achieving goals, choosing alternatives, actions against risk, and reactions under pressure. Personality types affect the ability of decision-makers to process large amounts of information, time pressure, and self-resilience. He also influences the rules and communication patterns of a decision maker. According to Kristianti (2012), personality is a dynamic organization and an individual psychophysical system that determines individual behavior and thinking in a typical way. Personality is also something that is contained in individuals who guide and give direction to individual behavior. So, personality types also influence the way decisions

Sanjaya Adi Putra, G., \& Dwirandra, A. A. N. B. (2019). The effect of auditor experience, type of personality and fraud auditing training on auditors ability in fraud detecting with professional skepticism as a mediation variable. International Research Journal of Management, IT and Social Sciences, 6(2), 31-43. https://doi.org/10.21744/irjmis.v6n2.604 
are made. Human personality types are divided into 4 preference pairs, namely, Extroversion and Introversion (EI), Sensing and Intuition (SN), Thinking and Feeling (TF), Judging and Perceiving (JP).

Research by Noviyanti (2008), states that a person's personality type is one of the factors that determine the attitude of the individual, including the skepticism that exists in the individual. Auditors with personality types ST (Sensing, Thinking) and NT (Intuition, Thinking) based on Myers-Briggs theory tend to be more skeptical. Because the auditor has personality traits that always make sense in making decisions based on facts. So that auditors with ST and NT personality types are more skeptical to detect fraud compared to other personality types.

Furthermore, it is not enough with experience, type of attitude and skepticism in detecting fraud, there are important factors in detecting fraud, namely an auditor must have sufficient knowledge in carrying out their duties. Increased knowledge will arise from the addition of formal training. In carrying out audits, public accountants must act like someone who is an expert in the field of accounting and auditing. Achievement of expertise begins with formal education, which is further expanded through experience in audit practices (Cristiawan, 2002). Public accountants must also undergo adequate technical training that covers both technical and general education aspects. Training here can be in the form of activities, such as seminars, symposiums, workshops, training itself and other skills support activities.

Fullerton \& Durtschi (2004), found that after training auditors who were respondents in their research, the difference between auditors who had low skepticism and auditors who had high skepticism became narrow for some characteristics. Fullerton \& Durtschi (2004), also found that training had a short-term effect on the ability of internal auditors to detect fraud. Based on this, it can be seen that training on fraud audits with more frequent intensities will increase skepticism and the auditor's ability to detect fraud. This is also in line with the research of Nasution \& Fitriany (2012), which examined the effect of audit experience and personality type on professional skepticism and the auditor's ability to detect fraud. This research is a replication of previous research conducted by Nasution \& Fitriany (2012) and Fullerton \& Durtschi (2004).

What distinguishes this research from previous research, namely: previous research samples take research samples to auditors who work in KAP in the city of Jakarta, while the focus of this research is on auditors who work in KAP in Bali Province. Then, the difference between this research and Nasution \& Fitriany (2012), research lies in the addition of variables, namely the researcher adds audit training variables in detecting fraud. Besides that, there is a difference from the previous research which is on the professional skepticism variable. Where Nasution \& Fitriany (2012), only make the professional skepticism variable as the dependent variable. Whereas in this study, researchers used the variable professional skepticism as the dependent variable and intervening variable. Skepticism is used as an intervening variable because in previous studies Fullerton \& Durtschi (2004), found no influence between auditor experience and ability to detect fraud, but in theory, it was influential, so this study tried to explain the influence of experience on the auditor's ability to detect fraud through professional skepticism.

\section{Literature Review}

According to Hilmi (2011), the experience is knowledge or expertise obtained from direct observation or participation in a real event and activity. Suraida (2005), revealed that experienced accountant examiners would make a relatively good judgment in professional assignments compared to inexperienced accountant examiners. Suraida (2005), also explains that experienced accountant examiners will show a higher level of selective attention to relevant information. From the description above, the research hypothesis is derived as follows:

H1: Audit experience has a positive effect on the auditor's professional skepticism.

NT (Intuition, Thinking) perceives information based on the possibilities that occur and considers it theoretically and scientifically in decision making. So that auditors with ST and NT combination personality types tend to be skeptical and very logical. This is supported by research conducted by Noviyanti (2008) and Nasution \& Fitriany (2012), which show that auditors with ST and NT personality types are auditors who have higher professional skepticism than auditors with other personality types. From the description above, the research hypothesis is derived as follows:

H2: ST and NT personality types have a positive effect on professional skepticism.

Fraud audit training is a type of training that discusses in depth about the techniques of an auditor in detecting fraud through various evidence in the form of a statement of testimony, author of the report and of course, very helpful auditor in detecting, preventing and disclosing fraud. In an effort to fulfill the requirements as a professional, the auditor must undergo adequate training. The more fraudulent audit training that is followed by auditors can increasingly produce various kinds of expectations in explaining audit findings. But if the auditor has never attended a fraud audit, it will be difficult to explain or find audit findings so that it can reduce his professional skepticism. Auditors who often 
attend training will always question and conduct evaluations critically based on the insights and understanding gained from the training. From the description above the research hypothesis is derived as follows:

H3: Fraud audit training has a positive effect on professional skepticism.

Auditors with little experience will find it more difficult to be able to detect fraud-related cases than experienced auditors who have found fraud cases. This statement is supported by research conducted by Hasanah (2010); Nasution \& Fitriany (2012), and Anggriawan (2014), who found that with a lot of auditory experience, it would improve the auditor's ability to detect fraud. From the description above, the research hypothesis is derived as follows:

H4: Audit experience has a positive effect on the auditor's ability to detect fraud.

Personality type can determine the person's choice for the job he likes. The accounting profession, such as auditing, is a profession that tends to be procedural because the scope of work is based on audit standards. Nurutami (2014), said that in collecting and evaluating audit evidence, professional judgment needed by auditors to provide adequate confidence, people who are able to always try to see something as evidence and be able to provide adequate confidence are people who have certain personality types. Based on these characteristics, it can be concluded that auditors who have ST and NT personality types are considered more logical to detect fraud that exists. From the description above, the research hypothesis is derived as follows:

H5: ST and NT personality types have a positive effect on the auditor's ability to detect fraud.

The results of the research from Noviyani (2012), show that training has a greater influence on improving expertise than those obtained from traditional programs, in this case only with the existing curriculum without training. The results of the study from Rahayu (2016), showed that fraud audit training had a positive effect on the auditor's ability to detect fraud in the scope of the Representative Office of West Kalimantan Province BPKP. Different research results were found in the Lhaksmi (2014), a study which showed that training in fraudulent audits was not proven to influence the auditor's ability to detect fraud. Based on the description above, the research hypothesis can be formulated as follows:

H6: Training has a positive effect on the auditor's ability to detect fraud.

Fullerton \& Durtschi (2004), prove that auditors with high skepticism will improve their ability to detect them by developing additional information seeking when faced with symptoms of fraud. This is supported by research conducted by Hasanah (2010); Nasution \& Fitriany (2012), and Anggriawan (2014), which show the same results so that it can be concluded that auditors who have a high professional skepticism must have a lot of relevant information so that can detect fraud easily. Based on the description above, the research hypothesis can be formulated as follows:

H7: Professional skepticism has a positive effect on the auditor's ability to detect fraud.

Tuanakota (2013), which states audit experience has a positive effect on detecting fraud by professional skepticism. This is supported by research conducted by Fullerton et al., (2004); Alwe et al., (2010), and Aufar (2014). The explanation shows that the amount of audit experience will indirectly affect the auditor's ability to detect fraud because a lot of audit experience makes auditors more skeptical. Based on the description above, the research hypothesis can be formulated as follows:

H8: Audit experience has a positive effect on the auditor's ability to detect fraud through professional skepticism.

When the auditor's professional skepticism is high, it will make the auditor easier to detect fraud. Because then the auditor continues to process the facts that exist until they find the fraud. This shows that the ST and NT personality types will indirectly affect the auditor's ability to detect fraud because ST and NT personality types will make auditors more skeptical. Based on the description above, the research hypothesis can be formulated as follows:

H9: ST and NT personality types have a positive effect on the auditor's ability to detect fraud through professional skepticism.

The level of knowledge and insight of an auditor can increase along with the amount of training that has been followed. With the knowledge and insights they have, an auditor can find out more easily in complex audit problems. This will also increase the auditor's caution in analyzing audit files. So that the many insights that an auditor has can affect his professional skepticism. an auditor has the responsibility to uncover fraud that will always try to be covered by fraudsters, for that attitude skepticism is very important to have so that an auditor can be more critical of audit evidence that is owned and not easy to believe before finding strong evidence. A high attitude of professional skepticism will minimize fraud that is not revealed. The higher the skepticism that an auditor has, the easier it will be to use intuition in recognizing errors that occur. The explanation above illustrates that the high level of knowledge and insight of an auditor obtained from cheating audit training will indirectly affect the auditor's ability to detect fraud.

Sanjaya Adi Putra, G., \& Dwirandra, A. A. N. B. (2019). The effect of auditor experience, type of personality and fraud auditing training on auditors ability in fraud detecting with professional skepticism as a mediation variable. International Research Journal of Management, IT and Social Sciences, 6(2), 31-43. https://doi.org/10.21744/irjmis.v6n2.604 
Based on the above explanation, the research hypothesis can be formulated as follows:

H10: Training has a positive effect on the auditor's ability to detect fraud through professional skepticism.

\section{Materials and Methods}

This research was conducted in 2018 at the public accounting offices in Bali Province which are still active and registered with the IAPI (Indonesian Institute of Certified Public Accountants). The scope of this research is behavioral aspects related to the influence of Audit Experience, Personality Type, Fraud Audit Training, and Professional Skepticism on the Auditor's Ability to Detect Fraud. The population in this study were auditors who worked at the Public Accounting Firm (KAP) in the Province of Bali. The sampling technique used is purposive sampling technique. The data collection method used in this study was by distributing questionnaires. The data analysis technique in this study uses the Partial Least Square (PLS) approach. PLS is SEM model based on components or variants.

\section{Results and Discussions}

PLS-SEM presents a coefficient of determination R2 that provides information on how much variation in the value of the independent variable can have an impact on changes in the dependent variable included in this study. If R $2 \geq$ 0.75 percent is obtained, it can be considered substantially that the role of the independent variable is sufficient as a predictor of changes in the value of the dependent variable included in the research model. However, if R2 $\geq 0.50$ is obtained, it can still be seen that the information presented by the independent variable is moderate, but if $\mathrm{R} 2<0.50$, then the variation of the dependent variable value that can be explained by the independent variable becomes very weak (Hair et al., 2011). Table 1 shows the R2 of each dependent variable in this study.

Table 1

R-square

\begin{tabular}{llc}
\hline \multicolumn{1}{c}{ Variable } & R Square & Keterangan \\
\hline Pengalaman Audit (X1) & & \\
Type Kepribadian (X2) & & Moderat \\
Pelatihan Audit Kecurangan (X3) & 0.715 & Kuat \\
Skeptisme Profesional (M) & 0.930 & \\
Kemampuan Mendeteksi Kecurangan (Y) & & \\
\hline
\end{tabular}

Primary Data, 2018

The results of the analysis of the value of R2 obtained from the calculation results show a wide range of distribution. Table 1 presents the results of calculations obtained by utilizing the SmartPLS version 3.6 software, which is R2. Based on Table 2, the R2 value for $\mathrm{M}$ is moderate, and R2 for $\mathrm{Y} 2$ is strong. If seen the distribution of R2 values as a whole, then it can be stated as a large dependent variable has relatively adequate information.

Table 2

Path Cofficients

\begin{tabular}{|c|c|c|c|c|}
\hline & $\begin{array}{c}\text { Original } \\
\text { Sampel } \\
\text { (O) }\end{array}$ & $\begin{array}{c}\text { Standard } \\
\text { Deviation } \\
\text { (STDEV) }\end{array}$ & $\begin{array}{l}\mathrm{T} \\
\text { statistics }\end{array}$ & $\begin{array}{c}\mathrm{P} \\
\text { Values }\end{array}$ \\
\hline Pengalaman Audit (X1) -> Skeptisme Profesional (M) & 0.400 & 0.435 & 2.919 & 0.000 \\
\hline $\begin{array}{l}\text { Pengalaman Audit (X1) -> Kemampuan Mendeteksi Kecurangan } \\
\text { (Y) }\end{array}$ & 0.766 & 0.233 & 2.711 & 0.008 \\
\hline Tipe Kepribadian (X2) -> Skeptisme Profesional (M) & 0.273 & 0.119 & 2.289 & 0.023 \\
\hline $\begin{array}{l}\text { Tipe Kepribadian (X2) -> Kemampuan Mendeteksi Kecurangan } \\
\text { (Y) }\end{array}$ & 0.314 & 0.090 & 3.505 & 0.001 \\
\hline
\end{tabular}


Pelatihan Audit Kecurangan (X3) -> Skeptisme Profesional (M)

0.470

0.124

2.371

0.000

Pelatihan Audit Kecurangan (X3) -> Kemampuan Mendeteksi

Kecurangan (Y)

Skeptisme Profesional (M) -> Kemampuan Mendeteksi

Kecurangan (Y)

$\begin{array}{llll}0.303 & 0.195 & 2.552 & 0.002\end{array}$

0.392

0.149

2.629

0.009

Primary Data, 2018

Table 2 shows that Audit Experience, Personality Types, and Training Fraud audits have a positive and significant effect on professional skepticism. Besides Audit Experience, Personality Types, Training Fraud audits and professional skepticism have a positive and significant effect on the ability to detect fraud. Because all variables have a P-Value less than 0.05 .

Furthermore, to find out the indirect effects of latent variables can be seen from the results of the analysis of the indirect effect values shown in Table 5.16. Based on Table 3, it is known that all mediation relationships in this test are positive and significant $(\mathrm{P}$ values $<0.05)$. The direct influence of audit experience, personality type, and professional skepticism on the ability to detect fraud has a significant effect, and after going through other variables or mediated by other variables to still show significant results. This shows that professional skepticism mediates partially (partial mediation) the influence of audit experience, personality type, and fraud audit training on the ability to detect fraud.

Table 3

Indirect Effects

\begin{tabular}{|c|c|c|c|c|c|}
\hline & $\begin{array}{l}\text { Variabel } \\
\text { Mediasi }\end{array}$ & $\begin{array}{c}\text { Original } \\
\text { Sampel } \\
(\mathrm{O})\end{array}$ & $\begin{array}{l}\text { Standard } \\
\text { Deviation } \\
\text { (STDEV) }\end{array}$ & $\begin{array}{c}\mathrm{T} \\
\text { statistics }\end{array}$ & P Values \\
\hline $\begin{array}{l}\text { Pengalaman Audit (X1) -> Kemampuan } \\
\text { Mendeteksi Kecurangan (Y) }\end{array}$ & (M) & 0.156 & 0.185 & 2.844 & 0.029 \\
\hline $\begin{array}{l}\text { Tipe Kepribadian (X2) -> Kemampuan } \\
\text { Mendeteksi Kecurangan (Y) }\end{array}$ & (M) & 0.107 & 0.054 & 1.999 & 0.047 \\
\hline $\begin{array}{l}\text { Pelatihan Audit Kecurangan (X3) -> } \\
\text { Kemampuan Mendeteksi Kecurangan (Y) }\end{array}$ & (M) & 0.184 & 0.055 & 2.202 & 0.030 \\
\hline
\end{tabular}

Primary Data, 2018

Furthermore, based on Table 2 and Table 3, a summary of the direct effects, indirect effects, and total influence between variables in this study can be presented, as in Table 4 Based on Table 5.17, it can be seen that directly or indirectly the influence of audit experience (X1), Personality Type (X2), and Training on Cheating Audit (X3) on the welfare of craftsmen (Y) has a significant positive effect. This proves that the variables of Professional Skepticism (M) mediate partially the influence of audit experience, personality type, and audit training on fraud on audit capabilities in detecting fraud.

Table 4

Summary

\begin{tabular}{lcccc}
\hline \multirow{2}{*}{ Dependent Construct } & \multicolumn{4}{c}{ Independent Constructions } \\
\cline { 2 - 5 } & $\begin{array}{c}\text { Professional } \\
\text { skepticism }\end{array}$ & $\begin{array}{c}\text { Audit } \\
\text { Experience }\end{array}$ & Personality type & $\begin{array}{c}\text { Fraud Audit } \\
\text { Training }\end{array}$ \\
\hline $\begin{array}{l}\text { Professional skepticism } \\
\begin{array}{l}\text { Direct influence } \\
\text { Indirect influence } \\
\text { Total Influence }\end{array}\end{array}$ & 0.400 & 0.273 & 0.470 \\
\hline $\begin{array}{l}\text { Ability to Detect Fraud } \\
\text { Direct Influence }\end{array}$ & 0.392 & 0.400 & 0.273 & 0.470 \\
\hline
\end{tabular}

Sanjaya Adi Putra, G., \& Dwirandra, A. A. N. B. (2019). The effect of auditor experience, type of personality and fraud auditing training on auditors ability in fraud detecting with professional skepticism as a mediation variable. International Research Journal of Management, IT and Social Sciences, 6(2), 31-43. https://doi.org/10.21744/irjmis.v6n2.604 


\begin{tabular}{lcccc} 
Indirect Effects & & 0.156 & 0.107 & 0.184 \\
Total Influence & 0.392 & 0.922 & 0.421 & 0.487 \\
\hline
\end{tabular}

Primary Data, 2018

The audit experience hypothesis has a positive effect on professional skepticism. The results of testing this hypothesis can be seen in table 5.15 shows that the relationship of audit experience variables with professional skepticism shows the path coefficient value of 0.400 with $t$-value of 2.919 . This value is greater than $t$ table 1,960 . This result means that audit experience has a positive and significant relationship to professional skepticism. The results of this study are consistent with the results of other studies by Suraida (2005), and Anugerah, Sari, and Frostiana (2011), which found a positive relationship between audit experience and professional skepticism. In the Grace, Essence, and Frostiana (2011) study, it was stated that the more auditor experience, the auditor's professional skepticism will increase. In addition, research by Shelton (2002) and Herliansyah \& Ilyas (2006), states that experienced auditors also prove to be more capable of selecting relevant information or evidence that is not relevant to making or making decisions.

The audit experience hypothesis has a positive effect on the auditor's ability to detect finances. The results of testing this hypothesis can be seen in table 5.15 shows that the relationship of audit experience variables with the ability to detect fraud shows the path coefficient value of 0.766 with t-value of 2.711 . This value is greater than t table 1,960 . This result means that the audit experience has a positive and significant relationship to the ability to detect fraud, so the audit experience hypothesis on the auditor's ability to detect finance supported by this study. This is in accordance with the theory which states that experience will provide lessons on the types of frauds that have been found by auditors so that the auditor saves a lot of things in his memory and can develop a good understanding of the cases faced. The results of this study are supported by the research of Hasanah (2010); Nasution \& Fitriany (2012), and Anggriawan (2014), who found a positive influence between experience and the auditor's ability to detect fraud.

The personality type hypothesis has a positive effect on professional skepticism. The results of testing the fifth hypothesis can be seen in table 5.15 shows that the relationship of personality type variables with professional skepticism shows the path coefficient value of 0.273 with t-value of 2.289 . This value is greater than t table 1,960 . This result means that the ST and NT personality types have a positive and significant relationship to professional skepticism, so the hypothesis of the personality type towards professional skepticism is supported by this study. This shows that auditors with ST and NT personality types have a high attitude of professional skepticism compared to personality types. Others, because the auditor with the personality type makes decisions based on the facts obtained by logical analysis. The results of this study are supported by research by Noviyanti (2008) and Nasution \& Fitriany (2012), who found that there were positive influences between auditors with ST and NT personality types with auditor skepticism.

The personality type hypothesis has a positive effect on the auditor's ability to detect fraud. The results of testing this hypothesis can be seen in table 5.15 shows that the relationship of personality type variables with the ability to detect fraud shows the path coefficient value of 0.314 with $\mathrm{t}$-value of 3.505 . This value is greater than $\mathrm{t}$ table 1,960 . Then the personality type has a positive effect on the ability to detect fraud. In this study the personality type was determined using the MBTI with four pairs of human preferences namely Extravert (E) and Introvert (I), Sensing (S) and Intuition $(\mathrm{N})$, Thinking $(\mathrm{T})$ and Feeling $(\mathrm{F})$, and Judging $(\mathrm{J})$ and Perceiving $(\mathrm{P})$. Auditors with a combination of ST and NT personality types are auditors who tend to think logically in making decisions and will consider all the facts to support their decision (Nasution and Fitriani, 2012). Individuals with personality type ST process information and make decisions based on the facts obtained by using logical analysis. While NT processes information based on possibilities that occur and considers it theoretically and scientifically in making decisions. The results of this study support the research conducted by Noviyanti (2008) and Nasution \& Fitriani (2012).

The cheating audit training hypothesis has a positive effect on professional skepticism. The results of testing this hypothesis can be seen in table 5.15 shows that the relationship of training variables with skepticism shows the path coefficient value of 0.470 with $t$-value of 2.371 . This value is greater than table 1,960 . This result means that training has a positive and significant relationship to skepticism which means it is consistent with the research hypothesis where training encourages professional skepticism of auditors. This shows that an auditor who has training more often tends to have high skepticism. The results of this study are supported by Fullerton \& Durtschi (2004), who conducted research on internal auditors in Canada and found that after being given training auditors who were initially less skeptical, they became more skeptical. This provides evidence that more often auditors taking part in training can increase auditor skepticism.

The cheating audit training hypothesis has a positive effect on the auditor's ability to detect finances. The results of testing this hypothesis can be seen in table 5.15 shows that the relationship of training variables with the ability to 
detect fraud shows the path coefficient value of 0.303 with value of 2.552 . This value is greater than t table 1,960 . This result means that training has a positive and significant relationship to the ability to detect fraud which means it is consistent with this hypothesis where training encourages the auditor's ability to detect fraud. This shows that an auditor who has more frequent training tends to be more able to detect fraud. Training will add auditor knowledge about the working environment, auditors are more sensitive to fraud red flags, so auditors are better able to detect fraud. The results of this study are supported by the study of Fullerton \& Durtschi (2004) and Halimi (2012), who found the same thing with this study

The hypothesis of professional skepticism has a positive effect on the auditor's ability to detect finances. The results of testing this hypothesis can be seen in table 5.15 shows that the variable relationship of professional skepticism with the auditor's ability to detect fraud shows the path coefficient value of 0.392 with t-value of 2,629 . This value is greater than table 1,960. This result means that professional skepticism has a positive and significant relationship to the auditor's ability to detect fraud, so the seventh hypothesis is supported by this research. This is consistent with the theory which states that auditors with high professional skepticism will improve their ability to detect it by developing a search for additional information when faced with symptoms of cheating. The results of this study are supported by the research of Fullerton \& Durtschi (2004), who examined the company's internal auditors, Hasanah (2010); Nasution \& Fitriany (2012); and Anggriawan (2014), who examined the external auditor proves that skepticism is needed because the more additional information obtained by the auditor, the more capable the auditor is to prove whether the symptoms of fraud are true or not.

Hypothesis testing the indirect effect of experience variables on the auditor's ability to detect fraud through professional skepticism. The test results of the influence of professional skepticism mediation variables on the influence of auditory experience with the auditor's ability to detect fraud can be seen from table 5.16. The path coefficient value is 0.156 with $t$-value of 2.844 . This value is greater than t table 1,960 . This study proves the mediating parameters of skepticism about the influence of experience with the ability to detect fraud are significantly positive. And from the test it can be said that an auditor who has high experience will tend to have a high attitude of professional skepticism too if the auditor is more skeptical, the auditor is better able to detect fraud

The hypothesis testing of the indirect influence of personality type variables on the auditor's ability to detect fraud through professional skepticism. The test results of the mediation effect of professional skepticism variables on the influence of personality types (PERSON) with the auditor's ability to detect fraud can be seen from table 5.16. The path coefficient value is 0.107 with the $t$ value of 1999 . This value is greater than $t$ table 1.960 . From the test, it is found that the mediation parameters are positive and significant. This means that professional skepticism mediates the relationship between personality type and auditor's ability to detect fraud, so the hypothesis is supported by this study. From the results of these tests, it can be concluded that an auditor who has the ST and NT personality types is able to detect fraud by increasing his professional skepticism first.

Hypothesis testing the indirect effect of fraud audit training variables on the auditor's ability to detect fraud through professional skepticism. The test results of the mediation effect of professional skepticism variables on the influence of personality types (PERSON) with the auditor's ability to detect fraud can be seen from table 5.16. The path coefficient value is 0.184 with a value of $\mathrm{t} 2.202$. This value is greater than table 1,960 . This study proves that the mediating parameter of skepticism about the influence of fraudulent audit training with the ability to detect fraud is positively significant. And from the test, it can be said that an auditor who follows cheating audit training will tend to have a high attitude of professional skepticism too. If the auditor is more skeptical, the auditor is better able to detect fraud.

\section{Conclusion}

This research was carried out with inseparable limitations. Therefore, it is hoped that similar studies will be expected to be able to minimize the limitations that exist. This study only uses a sample of auditors working in the Public Accountant Office in Bali province, so the results and conclusions of this study cannot be generalized to all external auditors in Indonesia. It is expected that further research can increase the number of public accounting firms that are sampled and expand the sample coverage area not only in the province of Bali so that the results of research with a higher generalization level can be obtained.

The variables that influence professional skepticism and the ability to detect fraud in this study are limited to audit experience variables, personality types and fraud audit training only. Therefore, researchers expect the next active

Sanjaya Adi Putra, G., \& Dwirandra, A. A. N. B. (2019). The effect of auditor experience, type of personality and fraud auditing training on auditors ability in fraud detecting with professional skepticism as a mediation variable. International Research Journal of Management, IT and Social Sciences, 6(2), 31-43. https://doi.org/10.21744/irjmis.v6n2.604 
participation of researchers to find other factors that influence professional skepticism and the ability to detect fraud. The data in this study are generated from instruments that are based on respondents' perceptions as answers so that it will cause problems if the respondents are dishonest, the answers will be different from reality. Future research should use direct interview techniques with auditors.

This research has several suggestions, namely, it is expected that the Public Accountants office in Bali Province will continue to improve training, especially fraud audit training for juniors and regardless of auditor position, so as to add auditor knowledge in detecting fraud. Auditors are expected to be able to maintain and improve skepticism and attitude of independence even though they have established long enough relationships with clients in conducting the audit process. Paying attention to all forms of related audit evidence, so that the auditor's ability to detect fraud is increasing. The auditor also increases his experience in auditing and training in order to increase his professional skepticism.

Conflict of interest statement and funding sources

The authors declared that they have no competing interest. The study was financed by personal funding.

\section{Statement of authorship}

The authors have a responsibility for the conception and design of the study. The authors have approved the final article.

\section{Acknowledgments}

The authors acknowledgment to the editor of IRJMIS for their valuable time, support and advice. 


\section{References}

Anggriawan, E. F. (2014). Pengaruh pengalaman kerja, skeptisme profesional dan tekanan waktu terhadap kemampuan auditor dalam mendeteksi fraud (Studi empiris pada Kantor Akuntan Publik di DIY). Nominal, Barometer Riset Akuntansi dan Manajemen, 3(2).

Anugerah, R., Sari, R. N., \& Frostiana, R. M. (2011). The Relationship between Ethics, Expertise, Audit Experience, Fraud Risk Assessment, and Audit Situational Factors and Auditor Profesional Skepticism. In International Symposium on Finance and Accounting.

Aufar, M. (2014). 7th Asia-Pacific Business Research Conference. Study of Post-Churn Impacts on Brand Image in Telecommunication Sector.

Aulia, D. N., \& Ismail, A. M. (2013). Residential satisfaction of middle income population: Medan city. ProcediaSocial and Behavioral Sciences, 105, 674-683.

Beasley, M. S. (1996). An empirical analysis of the relation between the board of director composition and financial statement fraud. Accounting review, 443-465.

Christiawan, Y. J. (2004). Kompetensi dan independensi akuntan publik: refleksi hasil penelitian empiris. Jurnal Akuntansi dan Keuangan, 4(2), 79-92.

Dwirandra, AANB \& I Ketut Suryanawa. (2018). Idealism and Professional Commitments Mediation the Effect of Work Experience and Training on Ethical Decision Making of Tax Consultan. Research Journal of Finance and Accounting. 9(21), pp. 85.94

Fitriany, H. N. (2012). Pengaruh Beban Kerja, Pengalaman Audit Dan Tipe Kepribadian Terhadap Skeptisme Profesional Dan Kemampuan Auditor Dalam Mendeteksi Kecurangan. Universitas Indonesia, Jakarta.

Fullerton, R., \& Durtschi, C. (2004). The effect of professional skepticism on the fraud detection skills of internal auditors. Available at SSRN 617062.

Hasanah, S. (2010). Pengaruh penerapan aturan etika, pengalaman dan skeptisme profesional auditor terhadap pendekteksian kecurangan: studi empiris beberapa kantor akuntan publik di dki jakarta.

Herliansyah, Y., \& Ilyas, M. (2006). Pengaruh Pengalaman Auditor Terhadap Penggunaan Bukti Tidak Relevan Dalam Auditor Judgment. SNA 9 Padang, 23-26.

Hilmi. (2011). Kepemimpinan Transformasional Dan Perilaku Kewarganegaraan Organisasional Di Politeknik Negeri Lhokseumawe. Jurnal perspektif Manajemen dan Perbankan, 2(1). 36-62,

Kristianti, I. (2012). Pengaruh Tipe Kepribadian dan Penerimaan Perilaku Disfungsional Terhadap Audit Judgement (Doctoral dissertation, Magister Akuntansi Program Pascasarjana FEB-UKSW).

Maulana, R., Opdenakker, M. C., \& Bosker, R. (2014). Teacher-student interpersonal relationships do change and affect academic motivation: A multilevel growth curve modelling. British journal of educational psychology, 84(3), 459-482.

Nasution, H. Fitriany. 2012. Pengaruh Beban Kerja, Pengalaman Audit dan Tipe Kepribadian Terhadap Skeptisme Profesional Dan kemampuan Auditor Dalam Mendeteksi Kecurangan. Jurnal dan Prosiding Simposium Nasional Akuntansi.

Noviyani, N. (2015). Pengaruh Perputaran Kas dan Perputaran Aktiva Tetap terhadap Profitabilitas pada Perusahaan Farmasi yang Terdaftar di Bursa Efek Indonesia (BEI) Periode Tahun 2002-2012 (Doctoral dissertation, UIN Sunan Gunung Djati Bandung).

Noviyanti, S. (2008). Skeptisme Profesional Auditor dalam Mendeteksi Kecurangan. Jurnal Akuntansi dan Keuangan Indonesia, 5(1), 102-125.

Nurutami, G. L. (2014). Pengaruh Penetapan Risiko Kekurangan dan Tipe Kepribadian Auditor Terhadap Skeptisisme Profesional Auditor (Doctoral dissertation, Universitas Pendidikan Indonesia).

Oktavia, A. L., Sentosa, S. U., \& Aimon, H. (2013). Analisis kurs dan money supply di Indonesia. Jurnal Kajian Ekonomi, 1(2).

Rahayu, S. K., \& Suhayati, E. (2010). Perpajakan Teori dan Teknis Perhitungan. Yogyakarta: Graha Ilmu, 139.

Shelton, A. M., Zhao, J. Z., \& Roush, R. T. (2002). Economic, ecological, food safety, and social consequences of the deployment of Bt transgenic plants. Annual review of entomology, 47(1), 845-881.

Suraida, I. (2005). Pengaruh etika, kompetensi, pengalaman audit dan risiko audit terhadap skeptisisme profesional auditor dan ketepatan pemberian opini akuntan publik. Sosiohumaniora, 7(3), 186.

Tuanakotta, T. M. (2011). Berpikir kritis dalam Auditing. Jakarta: Salemba Empat.

Turban, E., Liang, T. P., \& Aronson, J. E. (2005). Decision Support Systems and Intelligent Systems:(International Edition). Pearson Prentice Hall.

Sanjaya Adi Putra, G., \& Dwirandra, A. A. N. B. (2019). The effect of auditor experience, type of personality and fraud auditing training on auditors ability in fraud detecting with professional skepticism as a mediation variable. International Research Journal of Management, IT and Social Sciences, 6(2), 31-43. https://doi.org/10.21744/irjmis.v6n2.604 
Winantyadi, N., \& Waluyo, I. (2014). Pengaruh Pengalaman, Keahlian, Situasi Audit, dan Etika terhadap Skeptisisme Profesional Auditor (Studi Kasus pada KAP di Provinsi Daerah Istimewa Yogyakarta). Nominal, Barometer Riset Akuntansi dan Manajemen, 3(1). 


\section{Biography of Authors}

\begin{tabular}{|l|l||}
\hline Gede Sanjaya Adi Putra is interested in economics, especially accounting. He \\
graduated her bachelor degree in the Faculty of Economics and Business, Udayana \\
University, Bali in 2010. He currently is finishing his Master Degree in accounting \\
at Udayana University in 2019. \\
Email: sanjaya.cendul@gmail.com
\end{tabular}

Sanjaya Adi Putra, G., \& Dwirandra, A. A. N. B. (2019). The effect of auditor experience, type of personality and fraud auditing training on auditors ability in fraud detecting with professional skepticism as a mediation variable. International Research Journal of Management, IT and Social Sciences, 6(2), 31-43. https://doi.org/10.21744/irjmis.v6n2.604 